\title{
Pythium Root Rot of Seedling Geraniums Associated with High Levels of Nutrients
}

\section{L.A. Gladstone and G.W. Moorman \\ Department of Plant Pathology, The Pennsylvania State University, 211 \\ Buckhout Laboratory, University Park, PA 16802}

Seedling" geraniums (Pelargorzium $\times$ hortorum) are often grown at high fertilizer concentrations for rapid development. High fertilizer concentrations have been associated with decreased disease resistance (Gladstone and Moorman, 1989; Moorman, 1986) in some host/pathogen combinations and increased resistance in others (Beach, 1949; Chase and Poole, 1984).

The following research evaluates the effects of host nutrition on pythium root rot of seedling geranium cultivars that have been shown to be resistant or susceptible to Pythium ultimum Trow. (Gladstone and Moorman, 1989; Hausbeck, 1985), the casual agent of damping-off and root rot.

Geraniums chosen for these experiments were the susceptible (Gladstone and Moorman, 1989; Hausbeck, 1985) cultivars Showgirl (Harris-Moran Seed, Rochester, N. Y.) and Appleblossom Orbit (Goldsmith Seed, Gilroy, Calif.) and the resistant (Hausbeck, 1985) cultivar Red Elite (Goldsmith Seed). Two-week-old seedlings were transplanted into a peat : vermiculite : sand : bark : ash medium (Metro-Mix 350, W.R. Grace, Foglesville, $\mathrm{Pa}$.) in round 0.5 -liter plastic pots. Six weeks after planting, 15N-16P-17K soluble fertilizer (Peters Fertilizer Products, Fogelsville, Pa.) was applied at each irrigation. The concentrations of nutrients used were considered suboptimum (10.7 mM N), optimum $(21.4 \mathrm{~mm} \mathrm{~N})$, or excessive $(42.8 \mathrm{~mm}$ $\mathrm{N}$ ), based on previous reports (Mastalerz and Holcomb, 1982). The N concentrations (10.7, $21.4,42.8 \mathrm{~mm}$ ) are related to 100,300 , and $600 \mathrm{ppm} \mathrm{N}$, respectively. When fertilizer was applied, $\approx 10 \%$ to $15 \%$ of the liquid leached through the. potting medium.

Seven-day-old cultures of Pythium ultimum Trow. (American Type Culture Collection no. 32231, Rockville, Md.) on corn meal agar in $15 \times 100-\mathrm{mm}$ plastic petri plates were blended in tap water, $100 \mathrm{ml} /$ plate. Plants were inoculated 10 weeks after planting by pouring $10 \mathrm{ml}$ of the suspension on the potting medium surface.

Twelve plants of each cultivar at each fertilizer concentration were inoculated, while

Received for publication 17 Dec. 1987. Contribution no. 1678, Dept. of Plant Pathology, the Pennsylvania State Agr. Expt. Sta. Authorized for publication as Journal Series Paper no. 7843. The cost of publishing this paper was defrayed in part by the payment of page charges. Under postal regulations, this paper therefore must be hereby marked advertisement solely to indicate this fact.
12 were not. Plants were arranged on benches in three randomized complete blocks, with four inoculated and four noninoculated plants of each cultivar at each fertilizer concentration per block.

Plants were grown in a greenhouse that ranged from $21 \mathrm{C} /$ night to $28 \mathrm{C} /$ day. A distilled water-saturated paste extract of the potting medium from two pots of each cultivar from each fertilizer concentration was prepared weekly (Richards et al., 1954), and the conductivity and $\mathrm{pH}$ were measured.

Plants that were permanently wilted, had severe basal stem rot, or were obviously dead were categorized as "dead". Dead plants were counted weekly following inoculation and the cumulative total recorded. Data on cumulative plant mortality on the last observation date were subjected to analysis of variance of a split-split plot design using the statisticalanalysis system (SAS Institute, 1985).

The mortality rates for the noninoculated plants were significantly lower $(P=0.01)$ than for the inoculated plants (Tables 1 and 2). With the exception of 'Appleblossom Orbit' at the optimum fertilizer concentration, plant mortality was significantly greater $(P$ $=0.01$ ) at the excessive nutrient level for the inoculated population than at the optimum or suboptimum nutrient levels. No difference was detected in the relative susceptibility of the cultivars to pythium root rot. As the concentration of the nutrient salt given to the plant increased, plant mortality also increased (Table 1).

We demonstrated that when high fertilizer concentrations are used in growing seedling geraniums, there is greater risk of serious losses due to pythium root rot than when low concentrations are used. Seedling geranium cultivars previously considered either susceptible or resistant to pythium root rot reacted in a similar manner when inoculated with Pythium ultimum and exposed to excessive nutrient concentrations.

The cause of increased Pythium susceptibility in seedling geraniums at high fertilizer concentrations is not known. The results reported here clearly demonstrate the need to carefully select and define fertilizer concentrations used during geranium disease-resistance screening and strongly suggest the same be done in other host/pathogen systems.

\section{Literature Cited}

Beach, W.S. 1949. The effect of excess solutes, temperature, and moisture upon damping-off. Pa. Agr. Expt. Sta. Bul. 509:1-29.
Table 1. Average plant mortality, electrical conductivity, $\mathrm{pH}$, nutrient concentration, and cultivar of plants both inoculated with Pythium ultimum and noninoculated.

\begin{tabular}{|c|c|c|c|c|c|}
\hline Cultivar & $\mathrm{mM} \mathrm{N}$ & $\begin{array}{l}\text { Inocu- } \\
\text { lation }\end{array}$ & $E C^{z}$ & $\mathrm{pH}$ & $\begin{array}{c}\text { Avg } \\
\text { mortality } \\
(\%)\end{array}$ \\
\hline \multirow[t]{6}{*}{ Showgirl } & 10.7 & + & 1.6 & 6.6 & 1.3 \\
\hline & 10.7 & - & 1.6 & 6.6 & 0.0 \\
\hline & 21.4 & + & 3.8 & 6.1 & 1.6 \\
\hline & 21.4 & - & 3.8 & 6.1 & 0.6 \\
\hline & 42.8 & + & 5.4 & 5.8 & 2.6 \\
\hline & 42.8 & - & 5.4 & 5.8 & 0.6 \\
\hline \multirow[t]{6}{*}{ Red Elite } & 10.7 & + & 1.6 & 6.4 & 0.0 \\
\hline & 10.7 & - & 1.6 & 6.4 & 0.0 \\
\hline & 21.4 & + & 2.5 & 6.4 & 3.0 \\
\hline & 21.4 & - & 2.5 & 6.4 & 0.3 \\
\hline & 42.8 & + & 4.2 & 5.8 & 3.0 \\
\hline & 42.8 & - & 4.2 & 5.8 & 1.3 \\
\hline \multicolumn{6}{|l|}{ Appleblos- } \\
\hline \multirow[t]{6}{*}{ som Orbit } & 10.7 & + & 1.4 & 6.4 & 0.6 \\
\hline & 10.7 & - & 1.4 & 6.4 & 0.0 \\
\hline & 21.4 & + & 2.7 & 6.2 & 3.0 \\
\hline & 21.4 & - & 2.7 & 6.2 & 1.0 \\
\hline & 42.8 & + & 4.5 & 5.8 & 3.0 \\
\hline & 42.8 & - & 4.5 & 5.8 & 0.0 \\
\hline
\end{tabular}

${ }^{2} \mathrm{EC}$ is $\mathrm{x} 10^{-5} \mathrm{mhos} / \mathrm{cm}$.

Average plant mortality represents data collected from the last observation date (42 days after inoculation). Data were pooled from the replications within each "treatment.

Table 2. Analysis of variance of data collected from the last observation data.

\begin{tabular}{|c|c|c|c|c|}
\hline Source & $\mathrm{df}$ & $\begin{array}{l}\text { Sum of } \\
\text { squares }\end{array}$ & $\begin{array}{c}\text { Mean } \\
\text { square }\end{array}$ & $\mathrm{F}$ \\
\hline Block (Blk) & 2 & 9.0 & 4.5 & $6.07 * *$ \\
\hline Treatment (Trt) & 2 & 1.4 & 0.7 & 1.0 \\
\hline Blk $\times$ Trt & 4 & 3.8 & 1.0 & 1.3 \\
\hline Level (Lvl) & 2 & 19.1 & 9.5 & $12.9^{* *}$ \\
\hline Trt $\times$ Lvl & 4 & 8.1 & 2.0 & 2.7 \\
\hline Blk $\times$ Trt $\times$ Lvl & 12 & 13.7 & 1.1 & 1.6 \\
\hline Inoculation (Inoc) & 1 & 24.0 & 24.0 & $32.4^{* *}$ \\
\hline Trt $\times$ Inoc & 2 & 3.4 & 1.7 & 2.3 \\
\hline Trt $\times$ Lvl $\times$ Inoc & 6 & 7.2 & 1.2 & 1.6 \\
\hline Error & 18 & 13.3 & 0.7 & \\
\hline
\end{tabular}

**Significant at $P=0.01$.

Chase, A.R. and R.T. Poole. 1984. Investigations into the roles of fertilizer level and irrigation frequency on growth, quality, and severity of pythium root rot of Pepperomia obtusifolia. J. Amer. Soc. Hort. Sci. 109(5):619-622.

Gladstone, L.A. and G.W. Moorman. 1989. Pythium root rot of seedling geraniums associated with various concentrations of nitrogen, phosphorus, and sodium chloride. Plant Dis. 73:733-736.

Hausbeck, M.K. 1985. The effect of silver-thiosulfate and fungicides on pythium root rot of the seed propagated geranium. MS Thesis. Michigan State Univ., East Lansing.

Mastalerz, J. W. and E.J. Holcomb. 1982. Geraniums: A manual on the culture of geraniums as a greenhouse crop. Pennsylvania Flower Growers, University Park, Pa.

Moorman, G.W. 1986. Ircreased plant mortality caused by pythium root rot of poinsettia associated with high fertilization rates. Plant Dis. 70:160-162.

Richards, L.A. and U.S. Salinity Laboratory Staff. 1954. Diagnosis and improvement of saline and alkali soils. U.S. Dept. Agr. Hdbk. no. 60. p. 8-9.

SAS Institute, Inc. 1985. SAS user's guide: Statistics. 5th ed. SAS Institute, Cary, N.C. 